\title{
Malassezia spp DETECTED AT THE EDGE OF THE EYE OF A WHITE- EYED PARAKEET (Aratinga leucophthalma, STATIUS MULLER, 1776) - A CASE REPORT
}

\author{
DETECÇÃO DE Malassezia spp NO LIMBO DO OLHO DE PERIQUITÃO- \\ MARACANÃ (Aratinga leucophthalma, STATIUS MULLER, 1776)
}

\author{
Silvia Cassimiro BRASÃO ; Dayane Olímpia GOMES²; Gabriela Bim RAMOS²; \\ Andreia Zago CIUFFA ${ }^{1}$; Liliane Rangel NASCIMENTO² Anna Monteiro Correia LIMA $^{3}$; \\ André Luiz Quagliatto SANTOS 3 \\ 1. Residente em Medicina Veterinária Preventiva - Laboratório de Doenças Infectocontagiosas, - Faculdade de Medicina \\ Veterinária - FAMEV, Universidade Federal de Uberlândia - UFU, Uberlândia, MG, Brasil; 2. Mestranda em Ciências \\ Veterinárias - FAMEV - UFU, Uberlândia, MG, Brasil; 3. Professor, Doutor, FAMEV - UFU, Uberlândia, MG, Brasil
}

\begin{abstract}
The white-eyed parakeet (Aratinga leucophthalma), also known in Brazil as "periquitãomaracanã," "aratinga-de-bando," "araguaî́" and "maritaca," belongs to the family Psittacidae. The fungal genus Malassezia, which lives on the surface of the skin and mucosae of some mammals and birds, is a commensal organism that may sometimes act as a pathogen. This paper describes the presence of Malassezia spp at the edge of the eye of a white-eyed parakeet seized by IBAMA (Brazilian Institute of Environment and Renewable Natural Resources) and examined at the Federal University of Uberlândia (UFU) Veterinary Hospital. The examination of the bird revealed the presence of a small white rounded structure at the edge of its right eye. The bird was sedated and a fragment of the structure was removed and sent to the university's Laboratory of Infectious Diseases. This material was seeded in blood and MacConkey agars and a slide was prepared and stained by the Gram-staining technique; no biochemical assays were performed. Reading was performed in an optical microscope under 100X magnification, revealing flattened oval colonies resembling purplish footprints, indicative of Malassezia spp. The bird was not treated because the structure gradually diminished in size until it disappeared completely after the animal was isolated in a clean well ventilated place and supplied with water and good quality food suitable for the species. It is believed that the development of the atypical and uncommon foreign body in the bird's eye may have been caused by immunodepression resulting from the period of stress it underwent during wildlife trafficking.
\end{abstract}

KEYWORDS: Psittacidae. Fungus. Immunodepression.

\section{INTRODUCTION}

The white-eyed parakeet (Aratinga leucophthalma), also known in Brazil as aratingade-bando, araguaí, and maritaca, belongs to the Psittacidae family. This bird has an oval head, predominantly green feathers, and sometimes has a few red feathers on the sides of its head and neck, which are features common to both sexes (RUSCHI, 1979; SICK, 2001).

The birds of this genus are medium-sized compared to other psittacids, with body length varying from 25 to $33 \mathrm{~cm}$ (SICK, 2001), weight from 140 to $171 \mathrm{~g}$, and an average life expectancy of 30 years (MAHECHA et al., 2005).

According to an Activity Report of the CITES Secretariat (Convention on International Trade in Endangered Species of Wild Fauna and Flora, 2009), it is estimated that wildlife trafficking in Brazil amounts to around two billion dollars annually. This report also states that only one tenth of all trafficked animals survive after being taken from their natural habitat and enduring all the cruel and improper practices to which they are subjected during their capture, transportation and sale.

The practices used in the illegal wildlife trade have hardly evolved at all; handling and transportation are highly conducive to confinement without sufficient food or water, subjecting animals to stress and fights that often result in mutilation or death (BAMPI; OLIVEIRA, 2003).

The Psittacidae family is one of the favorites of wildlife trade due to its ornamental qualities and because there is a culture of breeding these animals in residential captivity (SOUZA; SOARES FILHO, 2005), resulting in their fear, stress or apathy.

Several birds kept in contact with each other promote a greater spread of infectious diseases. Dietary and management requirements vary between bird species living in a domestic environment, and the susceptibility of these animals to disease may be augmented when the levels of these parameters are below or above the ideal. Stressors, which include nutrition, management (overcrowding, maintenance of the 
bird), breed, and the introduction of new birds in the environment, can be significant contributing factors for the occurrence of diseases (JOSEPH, 2003)

Changes in the host's skin microenvironment and immune problems can cause colonies to act as opportunistic pathogens (GUILLOT, 1999; NOBRE et al., 2001; PRADO, 2007 cited by REIS-GOMES et al., 2012).

The genus Malassezia lives on the surface of the skin and mucous membranes of some mammals and birds; is a commensal organism that may eventually act as a pathogen (LOPES, 2008). This genus comprises thirteen distinct species of lipophilic yeast and Malassezia pachydermatis is the only nonlipodependent one (NARDONI et al., 2007; PRADO et al., 2008), i.e., it can be cultivated on Sabouraud dextrose agar (ZAITZ, RUIZ and SOUZA, 2000).

Malassezia species can be identified by their biochemical and morphological characteristics (GUILLOT et al., 1996), in which macroscopic aspects of the colony and microscopic aspects of the yeast are considered (PRADO et al., 2008).

In suitable media and at incubation temperatures of 35 to $37^{\circ} \mathrm{C}$, Malassezia spp. colonies have a creamy texture, brown to light brown, and a smooth or slightly rough surface (VARGAS et al., 2004).

This paper reports the presence of Malassezia spp. at the edge of the eye of a whiteeyed parakeet seized by the environmental authorities from a wildlife trafficker.

\section{Case report}

A white-eyed parakeet seized by IBAMA

(Brazilian Institute of Environment and

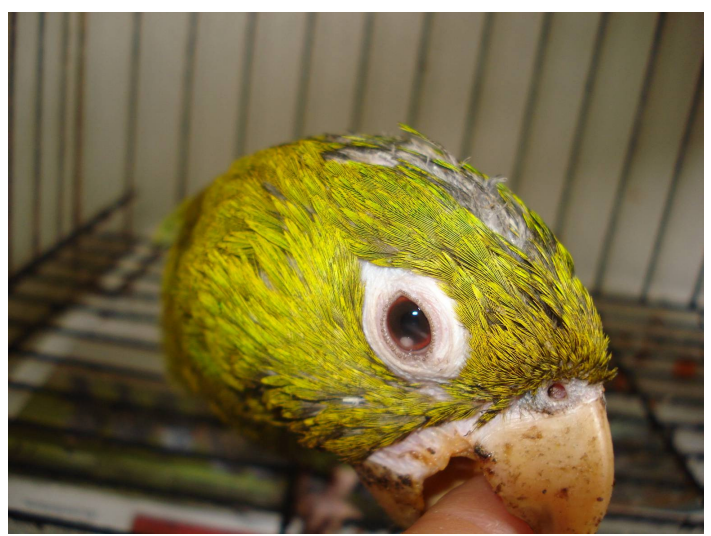

Figure 1. Small round opaque white structure at the edge of the bird's
Renewable Natural Resources) was examined at the Federal University of Uberlândia Veterinary Hospital in the wild animal outpatient clinic. An examination of the bird was revealed the presence of a small white opaque rounded structure at the edge of its right eye, in the transition zone between the cornea and sclera (Figure 1).

The bird was sedated with a dose of $5 \mathrm{mg} / \mathrm{kg}$ of Zoletil ${ }^{\circledR}$ (Tiletamine + zolazepam), after which a fragment of the structure was removed, inoculated in BHI (Brain Heart Infusion), and sent to the university's Laboratory of Infectious Diseases.

This material was kept in an incubator at $37^{\circ} \mathrm{C}$ for 24 hours, after which the turbidity was observed. It was then seeded on blood agar plates - enriched with 5\% sheep blood - and MacConkey agar, and incubated again at the same above mentioned temperature and time, for bacterial growth (Quinn et al., 2005). A glass slide was prepared by Gram's staining method and examined in an ordinary microscope under an immersion lens (100X magnification) to identify the agent.

Based on the colony morphology, the analysis of the microbial species indicated the presence of purplish colored oval colonies, isolated or grouped in clusters, indicative of Malassezia spp (Figure 2). No biochemical assays were performed.

The bird was not treated with drugs because the structure gradually diminished until it disappeared completely. The only changes effected during this period were to isolate the bird in a clean place with fresh air and provide it with water and of good quality food suitable for the species.

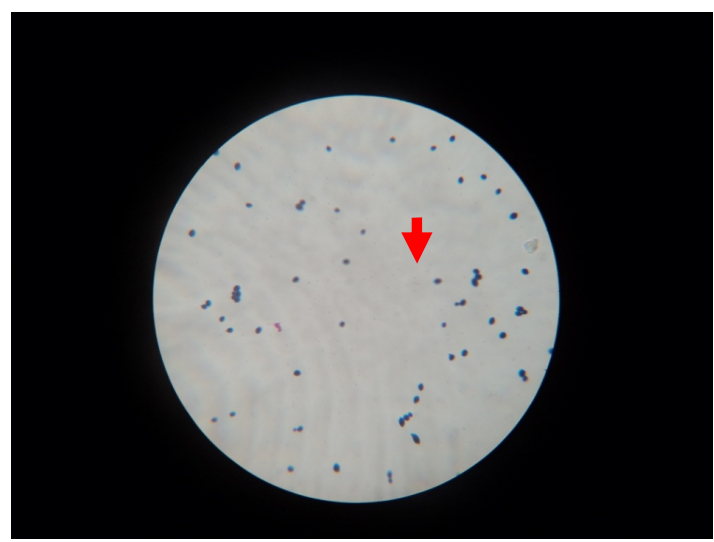

Figure 2. Colonies observed in an ordinary microscope at 100X magnification 


\section{DISCUSSION}

The diagnosis of colony infections is made by direct observation using cytological, culture and histopathological techniques (NEGRE, BENSIGNOR; GUILLOT, 2008). Staining is indispensable (with Gram stain kits), and lipophilic colonies are easily identified under an immersion lens (LAUTERTE, 2010).

M. pachydermatis forms colonies with a creamy appearance and soft or friable texture, and micromorphology reveals small oval cells. The ideal temperature for its development is $37^{\circ} \mathrm{C}$ (CHRYSSANTHOU, BROBERGER; PETRINI, 2001; SCHLOTTFELDT et al., 2002 cited by MARASCHIN et al., 2008). This is the only species of the genus Malassezia that is non-lipo-dependent (GUILLOT; GUÉHO, 1995). According to Guillot et al. (1996) non-lipo-dependent yeasts can grow in ordinary culture medium such as blood agar, which is a medium free of lipid supplements (QUINN et al., 2005).

The importance of the colonies of the genus Malassezia has increased since it became recognized as one of the important pathogens in patients suffering from some type of immunodepression (ZAITZ, RUIZ; SOUZA, 2000).

In veterinary medicine, Malassezia spp. is known to participate in the microflora and in the etiopathogenesis of some diseases, particularly dermatitis and otitis, in both domestic and wild animals (PRADO et al., 2008).

$M$. pachydermatis has also been found in the healthy skin of a variety of animals, such as rabbits, pigs, sheep, goats, cows, horses, guinea pigs, rhinoceros, elephants, deer, birds, primates, bears, ferrets, seals, foxes and anteaters (CRESPO, ALBARCA; CABANES, 2002).

Systemic diseases have been observed in $35 \%$ of animals with eye diseases, and in addition to causing ocular changes, they are responsible for the impairment of animal immunity and, hence, for the establishment of various opportunistic diseases (BRITO, ALVES; LAUS, 1998).

The first report of $M$. pachydermatis was described in two specimens of scarlet macaw (BREUER-STROSBERG, HOCHLEITHNER and KUTTIN, 1990), in which the history of the birds described them as having low body weight and pectoral muscle atrophy, and an endoscopic examination revealed an ulcer in the birds' corneal membrane. Like in the case of this report, the agent was isolated on blood agar and the colonies were examined after culturing at a temperature of $37^{\circ} \mathrm{C}$.

In psittacids, Preziosi et al. (2006) found Malassezia spp in the intact skin and in skin lesions caused by feather self-mutilation, upon cytological examination of the fungal culture and PCR (polymerase chain reaction).

The presence of fungi in the conjunctiva can pose a constant threat to the eyes in conditions of low immunity (PETROCINIO, COLOMBINI and MANDARINO, 2006). Captive animals are commonly exposed to bacteria and fungi in the environment, whether through food, water, fomites, or even by other animal companions. This fact is aggravated in overcrowded environments, where there is greater physical contact among animals and intraspecific competition, which often lead an immunocompromised state of the individual, either through stress or even due to malnutrition, favoring infection by opportunistic agents (TULLY, 1995).

\section{CONCLUSION}

It is believed that the agent may have developed in an atypical and unusual way in the bird's eye due to the animal's immunodepression, which is explained by the period of stress it underwent during trafficking. The changes in environment and food sufficed to restore the bird's health.

RESUMO: O periquitão-maracanã (Aratinga leucophthalma), também conhecido como aratinga-de-bando, araguaí e maritaca, pertence à família Psittacidae. O gênero Malassezia vive na superfície da pele e mucosas de alguns mamíferos e aves; é um organismo comensal que, eventualmente, pode agir como patógeno. O objetivo deste foi relatar a presença de Malassezia spp no limbo do olho de um exemplar de periquitão-maracanã apreendido pelo IBAMA (Instituto Brasileiro do Meio Ambiente e dos Recursos Naturais Renováveis) e atendido no Hospital Veterinário da Universidade Federal de Uberlândia (UFU). Durante a anamnese, foi observada a presença de uma pequena estrutura branca no limbo do olho direito da ave. A ave foi sedada, e foi colhido um fragmento da estrutura, o qual foi encaminhado ao Laboratório de Doenças Infectocontagiosas da UFU. Esse material foi semeado em ágares Sangue e MacConkey. E, após observado o crescimento de colônias apenas no meio ágar Sangue, confeccionou-se uma lâmina, corando-a pelo método de Gram; não foram realizados testes bioquímicos . A leitura realizou-se em microscópio óptico no aumento de 100 vezes, e observaramse colônias ovaladas e achatadas, semelhantes a pegadas de sapatos, e de coloração púrpura, indicativo de Malassezia spp. Foi realizado o isolamento da ave em local limpo e arejado, e o fornecimento de água e alimentos de boa qualidade, compatíveis com a espécie, sendo estas as únicas alterações procedidas nesse período, não necessitando de tratamento, 
pois houve diminuição da estrutura até seu total desaparecimento. Acredita-se que o agente possa ter se desenvolvido de forma atípica e incomum no olho, devido à imunodepressão da ave, justificada pelo período de estresse ao qual ela foi submetida durante o tráfico.

PALAVRAS-CHAVE: Psittacidae. Fungo. Imunodepressão.

\section{REFERENCES}

BAMPI; M. I.; OLIVEIRA, L. H. A Convenção sobre o Comércio Internacional de Espécies da Fauna e Flora Selvagem em Perigo de Extinção - CITES e sua implementação pelo governo brasileiro. In: REDE NACIONAL DE COMBATE AO TRÁFICO DE ANIMAISSILVESTRES (RENCTAS) (Org.). Animais Silvestres: vida à venda. 2.ed. Brasília: Dupligráfica, 2003.

BREUER-STROSBERG, R.; HOCHLEITHNER, M.; KUTTIN, E. S. Malassezia pachydermatis isolation from a scarlet macaw. Mycoses, Berlim, v. 33, n. 5, p. 247-50, maio 1990.

BRITO, F. L. C.; ALVES, L. C.; LAUS, J. L. Manifestações oculares na leishmaniose visceral canina - revisão. Revista Clínica Veterinária, São Paulo, n. 64, p. 68-74, 1998.

CRESPO, M. J.; ABARCA, M. L.; CABAÑES, F. J. Occurrence of Malassezia spp. in the external ear canals of dogs and cats with and without otitis externa. Medical Mycology, Oxford, v. 40, p. 115-121, 2002.

http://dx.doi.org/10.1080/mmy.40.2.115.121

CONVENTION ON INTERNATIONAL TRADE IN ENDANGERED SPECIES OF WILD FAUNA AND FLORA (CITES). Activity report of the CITES Secretariat. 2009. Available at:

<http://www.cites.org/eng/disc/sec/ann_rep/2008-09.pdf>. Accessed on: 07 aug. 2013.

GUILLOT, J.; GUÉHO, E.; LESOURD, M.; MIDGLEY, G.; CHÉVRIER, G.; DUPONT, B. Identification of Malassezia species. A practical approach. Journal of Medical Mycology, Paris, v. 6, p. 103-110, 1996.

GUILLOT, J.; GUÉHO, E. The diversity of Malassezia yeasts confirmed by rRNA sequence and nuclear DNA comparison. Antonie van Leeuwenhoek, Dordrecht, v. 5, p. 297-314, 1995.

http://dx.doi.org/10.1007/BF00873693

JOSEPH, V. Infectious and parasitic diseases of captive passerines. Seminars in Avian and Exotic Pet Medicine, Bristol, v. 12, n. 1, p. 21-28, 2003. http://dx.doi.org/10.1053/saep.2003.127878

LAUTERTE, C. Caracterização de isolados do fungo Malassezia pachydermatis através do perfil enzimático. 2010. 52f. Dissertação (Mestrado em Ciências Veterinárias) - Universidade Federal do Rio Grande do Sul. Faculdade de Medicina Veterinária, Porto Alegre, 2010.

LOPES, R. J. Dermatitis canina por Malassezia. REDVET - Revista electrónica de Veterinaria, v. 9, n. 5, 2008. Available at: <http://www.veterinaria.org/revistas/redvet/n050508.html>. Accessed on: 10 apr. 2013.

MAHECHA, J. V. R; SUÁREZ, F. R.; ARZUZA, D. E.; HERNÁNDEZ, A. G. Loros, Pericos and Guacamayas Neotropicales. Panamericana Formas e Impresos S.A., Bogotá D. C., p. 69, 2005.

MARASCHIN, M. M.; SPADER, T.; MARIO, D. A. N.; ROSSATO, L.; LOPES, P. G. M. Infecções causadas por Malassezia: Novas abordagens. Saúde, Santa Maria, v. 34a, n. 1-2, p. 4-8, 2008.

NARDONI, S.; DINI, M.; TACCINI, F.; MANCIANTI, F. Occurrence, distribution and population size of Malassezia pachydermatis on skin and mucosa of atopic dogs. Veterinary Microbiology, São Paulo, v. 16, n. 122, p. 172-177, 2007. http://dx.doi.org/10.1016/j.vetmic.2006.12.023 
NEGRE, A.; BENSIGNOR, E.; GUILLOT, J. Evidence-based veterinary dermatology: a systematic review of interventions for Malassezia dermatitis in dogs. Veterinary Dermatology, USA, v. 20, p. 1-12, 2008. http://dx.doi.org/10.1111/j.1365-3164.2008.00721.x

PETROCINIO, R. R.; COLOMBINI, G.; MANDARINO, J. R. Perfil da microbiota conjuntival em pacientes HIV positivos. Revista Brasileira de Oftalmologia, Rio de Janeiro, v. 65, p.6-73, 2006.

PRADO, M. R.; BRILHANTE, R. S. N.; CORDEIRO, R. A.; MONTEIRO, A. J.; SIDRIM, J. J. C.; ROCHA, M. F. G. Frequency of yeasts and dermatophytes from healthy and diseased dogs. Journal of Veterinary Diagnostic Investigation, Columbia, v. 20, p. 197-202, 2008. http://dx.doi.org/10.1177/104063870802000208

PREZIOSI, D. E.; MORRIS, D.O.; JOHNSTON, M. S.; ROSENTHAL, K. L.; O'SHEA, K.; RANKIN, S. C. Distribution of Malassezia organisms on the skin of unaffected psittacine birds and psittacine birds with feather-destructive behavior. Journal of the American Veterinary Medical Association, Schaumburg, v. 228, n. 2, p. 216-21, 2006. http://dx.doi.org/10.2460/javma.228.2.216

QUINN, P. J.; MARKEY, B. K.; CARTER, M. E.; DONNELLY, W. J. C.; LEONARD, F. C.; MAGUIRE, D. In: Microbiologia Veterinária e Doenças Infecciosas. Porto Alegre: Artmed, 2005. 512 p.

REIS-GOMES, A.; MADRID, I. M.; MATOS, C. B.; TELLES, A. J.; WALLER, S. B.; NOBRE, M. O.; MEIRELES, M. C. A. Dermatopatias fúngicas: aspectos clínicos, diagnósticos e terapêuticos. Acta Veterinaria Brasilica, Mossoró, v. 6, n. 4, p. 272-284, 2012.

RUSCHI, A. Aves do Brasil. São Paulo: Rios, 1979. 335 p.

SICK, H. Ornitologia Brasileira. 4. ed. Rio de Janeiro: Nova Fronteira, 2001. 922p.

SOUZA, G. M.; SOARES FILHO, A. O. O comércio ilegal de aves silvestres na região do Paraguaçu e Sudoeste da Bahia. Enciclopédia Biosfera, Goiânia, v. 1, p. 1-11, 2005.

TULLY, T. N. Jr. Avian Respiratory Diseases: Clinical Overview. Journal of Avian Medicine and Surgery, New York, v. 9, n. 3, p. 162-174, 1995.

VARGAS, V. E. S.; GOMPERTZ, O. F.; SIDRIM, J. J. C.; JARABRAN, M. C. D. Pitiríase versicolor e doenças por Malassezia spp. In: SIDRIM, J. J. C; ROCHA M. F. G. Micologia Médica à Luz de Autores Contemporâneos, Rio de Janeiro: Guanabara Koogan S.A., p. 112-123, 2004.

ZAITZ, C.; RUIZ, L. R. B.; SOUZA, V. M. Dermatoses associadas às leveduras do gênero Malassezia. Anais Brasileiros de Dermatologia, Rio de Janeiro, v. 75, n. 2, p. 129-142, mar/abr. 2000. 